\title{
Development of mobile application for Malay translated hadith search engine
}

\author{
Nurazzah Abd Rahman, Faiz Ikhwan Mohd Rafhan Syamil, Shaiful Bakhtiar bin Rodzman \\ Faculty of Computer \& Mathematical Sciences, Universiti Teknologi MARA, Malaysia
}

\begin{tabular}{l}
\hline \hline Article Info \\
\hline Article history: \\
Received Feb 7, 2020 \\
Revised Apr 9, 2020 \\
Accepted Apr 18, 2020 \\
\hline
\end{tabular}

\section{Keywords:}

Malay translated hadith

Mobile application

Search engine

\begin{abstract}
This paper presents the development of mobile application for Malay Translated Hadith search engine. Limitations of current Hadith web application are the design is to optimize its usage on desktop computer but not on mobile devices, which requires simple and user friendly interface. Besides that, web application also needs internet connection to use. Due to increase usage of mobile application among mobile phone users, many existing web applications have moved to mobile based applications to cater for increasing numbers of mobile users. In this study, a mobile application for Android and iOS mobile application has been developed using Flutter framework, a hybrid mobile application framework. A Malay Translated hadith search engine mobile application can easily assist those who are seeking knowledge to learn more about certain topics in hadith, a second source of Islamic knowledge. This mobile application has search and directory features for users to browse the 2028 Sahih Bukhari hadith collection. Users can enter their query using search features to find selected hadith in Malay language. Queries will be processed for searching relevant hadith and display the results to the user. Evaluation using Recall and Precision shows that on the average Recall is $73 \%$ and Precision is 33\%. Functionality testing is also conducted to test against the functional requirements or specifications. Results shows all requirements are successfully tested.
\end{abstract}

Copyright $\odot 2020$ Institute of Advanced Engineering and Science. All rights reserved.

\section{Corresponding Author:}

Nurazzah Abd Rahman,

Faculty of Computer \& Mathematical Sciences,

Universiti Teknologi MARA,

Shah Alam, Selangor Darul Ehsan, Malaysia.

Email: nurazzah@fskm.uitm.edu.my

\section{INTRODUCTION}

Current records showed approximately 4.68 billion people worldwide own a smartphone [1, 2]. Mobile app usage is growing 6\% Year-on-year [3, 4]. There are a few mobile operating systems. The top popular mobile operating systems are Android and iOS, but others include BlackBerry OS, webOS, and watchOS $[4,5]$.

Malay language has been a spoken language widely especially for countries in Southeast Asia. Malay language became the lingua franca among traders who travelled through Malacca in the 15th century [6]. The language is still widely spoken in Malaysia, Indonesia, and Brunei, many Singaporean and Southern Thailand also speak the language [7]. According to Khairul et. al., Malay language is among the top ten most used languages on the web [8].

Sunnah refers to all that is narrated from the Prophet Muhammad: his acts, his sayings and whatever he tacitly approved [9]. Many of the companions of the Prophet Muhammad memorized and wrote down Prophet's statements and actions to pass down the hadiths to their students. Several Muslim scholars collected these hadiths into compilations which have become widespread and are the main sources of hadiths 
until today [10]. As the technology is prospering, an effort to accommodate Muslims from Malay speaking countries can be done by developing a mobile application to retrieve Malay Hadith text [11].

Hadith Collection from Greentech Apps Foundation [12] contains more than 41,000 hadith from most accepted and authentic Hadith, available in English and Arabic Language only. Partial match query for Hadith Collection application is very lagging [12]. Hadith Collection - Sahih Bukhari, Muslim \& More from Quarter Pi: Best pro-Islamic apps for Muslim Ummah features powerful search engine for pro version only and does not support search engine for the free version [13]. Hadith Sahih Al Bukhari Malay from Ar-Rahman Labs features Complete Sahih Bukhari book in Malay but this application only supports keyword search [14]. Mutiara Hadis is the pioneer of the Malay Hadith Information Retrieval [15-20]. It is one of the web-based application search engines for hadith translated in Malay language. Portal myHadith is a webbased application search engine developed by Jabatan Kemajuan Islam Malaysia (JAKIM) for hadith translated in Malay language [21]. Users need to have internet connection to use this website. By having a mobile application, users do not need any internet to use the application. There is a need to have a simple and easy search engine in mobile platform with an attractive interface to attract more users to use this application [11]. The hadiths collections that are published either in form of digital sources or books are limited for other languages except Arabic, English and Indonesian [22, 23]. This research aims to develop a mobile application search engine for Malay translated hadith for fast and easy searching in assisting targeted users to satisfy their information needs.

\section{RESEARCH METHOD}

The whole process of Information Retrieval is illustrated in Figure 1 [23, 24]. In the Text Operations, Malay Translated Hadith corpus will be pre-processed by tokenizing, removing stop words and stemming to get the index terms and produce the inverted indexed file. Natural language queries that represent user's information need will be processed by text operations resemble those applied to Hadith text corpus to obtain the keywords which are used to search from the indexed file to retrieve the set of relevant Hadith documents. These retrieved documents will be ranked using selected ranking algorithm and return back to the user for further usage.

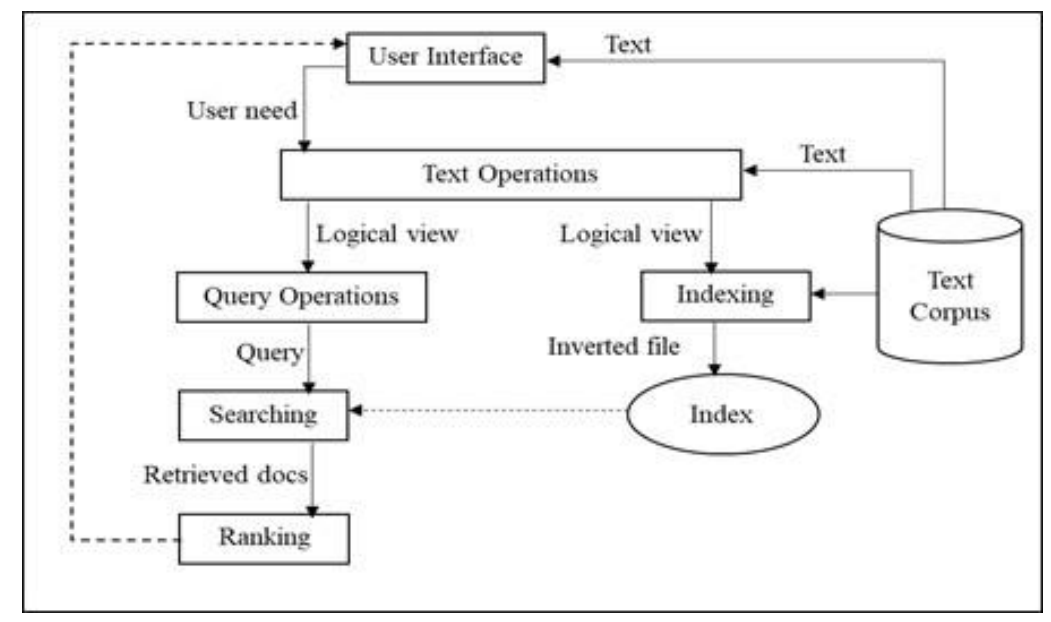

Figure 1. Information retrieval process [24]

This research focused on 2,028 hadith Sahih Bukhari documents [22, 25]. All documents are indexed using inverted indexed file. Stop words which carry no meaning, will be removed. Total Malay Language stop words used in this research is 365 words [25]. For example, token of strings "Saya", "nak", "tahu", "mengenai", "makanan" will be reduced to become "makanan" after removing stop words. Stemming is a process to reduce a word to its root form [25]. For example, term "makanan" will be stemmed to its root word "makan". Dictionary for Malay root word and morphological rules for Malay language are applied in the stemming process [16]. Lastly, the stemmed word are used as keywords to search from the indexed file before the retrieved documents are ranked and displayed to the user [16, 26, 27].

A proper user interface and user experience for mobile application are crucial. This is because by having a small screen on mobile devices, user must be able to interact with the application effectively. Activities or view 
controller are referred to the interface for each event. Currently, there are five different activities or view controller as planned for the user interface. The activities are named as splash screen, menu activity, search pop up, type activity and hadith activity. Figure 2, Figure 3, Figure 4, Figure 5, and Figure 6, shows the user interface for splash screen, menu activity, search pop up, type activity and hadith activity, respectively.

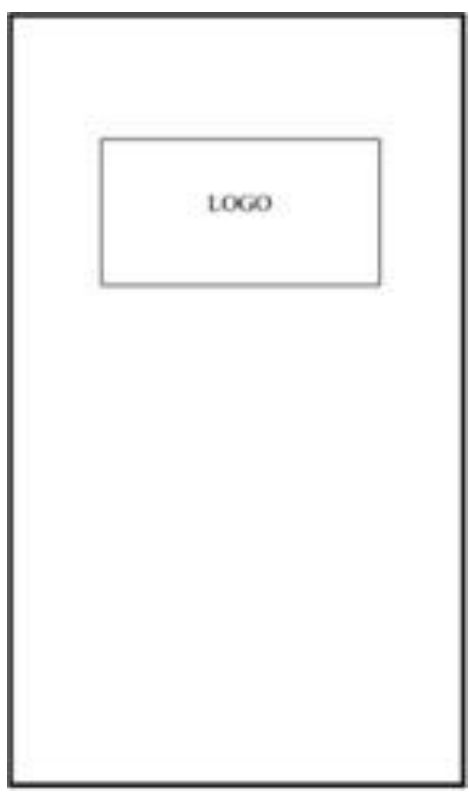

Figure 2. Splash screen

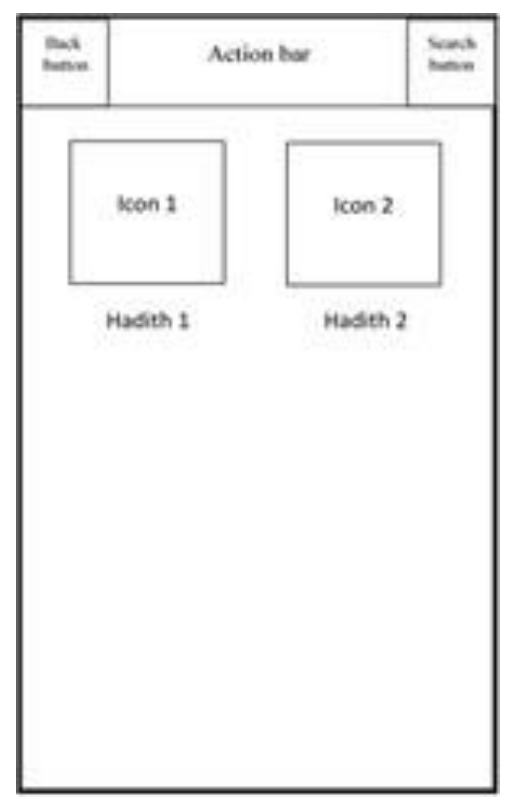

Figure 3. Menu activity

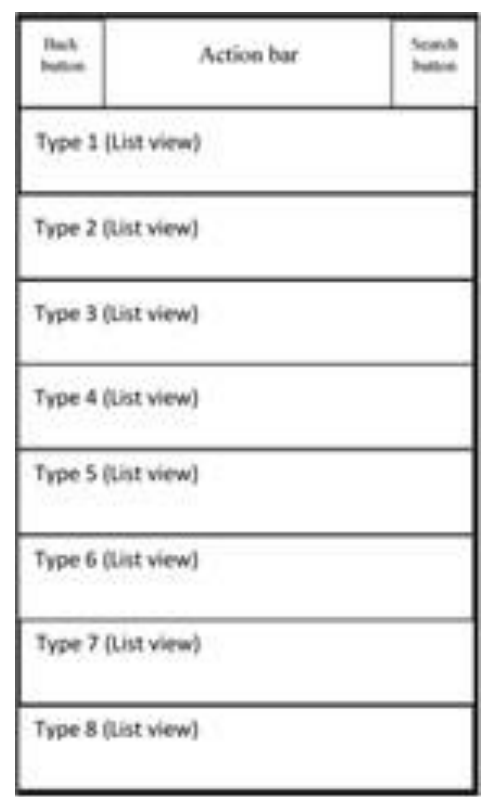

Figure 4. Search popup

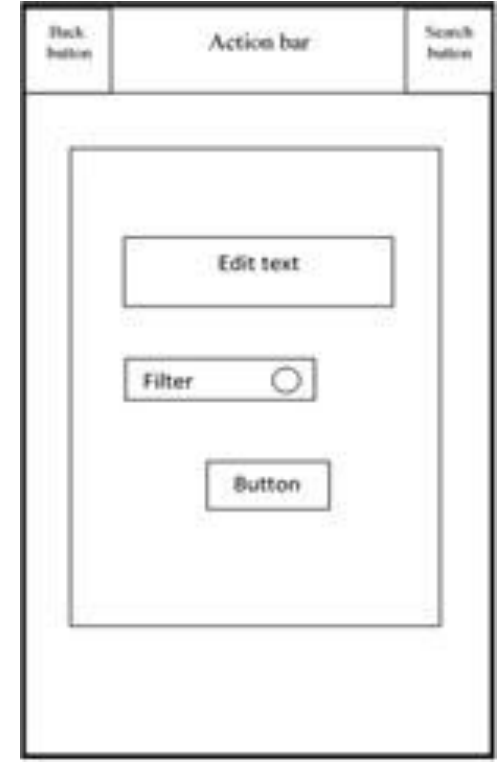

Figure 5. Type activity

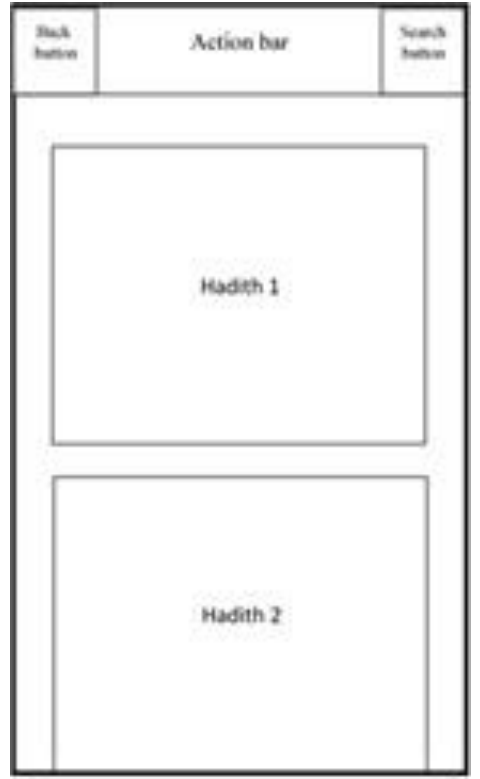

Figure 6. Hadith activity

Development of the mobile application prototype requires software such as integrated development environment (IDE), programming language and framework to use. This research is developed for iOS and Android operating system using a hybrid framework called Flutter framework. The software used for this research are Android Studio, Android emulator and iOS emulator. Dart programming language is used for Flutter framework. The hardware requirement to develop this research are in Table 1. It requires mobile phone with Android and IOS operating system. 
Table 1. Hardware requirement

\begin{tabular}{lll}
\hline \multicolumn{1}{c}{ Computer } & \multicolumn{1}{c}{ Android smartphone } & iOS smartphone \\
\hline \multicolumn{1}{c}{ MacBook Air } & \multicolumn{1}{c}{ Oppo A3s } & Apple iPhone 6S \\
macOS Mojave Version 10.14.5 & Android version 8.1.0 & iOS 12.2 \\
1.8GHz dual-core Intel Core i5 processor & Qualcomm SDM450 Octa Core Processor & A9 \\
8GB 1600MHz LPDDR3 memory & 2GB RAM & $2 \mathrm{~GB}$ RAM \\
256GB SSD storage & 16GB ROM & $32 \mathrm{~GB}$ ROM \\
Intel HD Graphics 6000 & & \\
\hline
\end{tabular}

\section{RESULTS AND ANALYSIS}

This section discussed on the evaluation of the results. A test is conducted by running 30 different queries from [25, 28-30]. Then, the displayed result will be compared with relevant judgment from [25]. The result presented in Table 2 is evaluated using standard Recall and Precision evaluation criteria [24].

Table 2. Query result analysis

\begin{tabular}{|c|c|c|c|c|c|}
\hline $\begin{array}{l}\text { Query } \\
\text { No }\end{array}$ & $\begin{array}{l}\text { Relevant Judgement } \\
\text { (Rel) }\end{array}$ & $\begin{array}{l}\text { Query Result } \\
\text { (A) }\end{array}$ & $(\operatorname{Rel} \cap A)$ & $\begin{array}{c}\text { Recall } \\
\mid \text { Rel } \cap \text { A } \mid \\
\mid \text { Rel } \mid\end{array}$ & $\begin{array}{c}\text { Precision } \\
\frac{\mid \text { Rel } \cap \mathrm{A} \mid}{|\mathrm{A}|}\end{array}$ \\
\hline 1 & 19 & 16 & 13 & 0.68 & 0.81 \\
\hline 2 & 50 & 252 & 48 & 0.96 & 0.19 \\
\hline 3 & 47 & 202 & 45 & 0.96 & 0.22 \\
\hline 4 & 8 & 352 & 6 & 0.75 & 0.02 \\
\hline 5 & 19 & 30 & 19 & 1.00 & 0.63 \\
\hline 6 & 8 & 65 & 5 & 0.63 & 0.08 \\
\hline 7 & 64 & 586 & 54 & 0.84 & 0.09 \\
\hline 8 & 7 & 39 & 4 & 0.57 & 0.10 \\
\hline 9 & 81 & 116 & 61 & 0.75 & 0.53 \\
\hline 10 & 18 & 214 & 18 & 1.00 & 0.08 \\
\hline 11 & 32 & 77 & 3 & 0.09 & 0.04 \\
\hline 12 & 11 & 41 & 11 & 1.00 & 0.27 \\
\hline 13 & 55 & 199 & 55 & 1.00 & 0.28 \\
\hline 14 & 28 & 113 & 27 & 0.96 & 0.24 \\
\hline 15 & 31 & 84 & 24 & 0.77 & 0.29 \\
\hline 16 & 14 & 255 & 6 & 0.43 & 0.02 \\
\hline 17 & 54 & 189 & 53 & 0.98 & 0.28 \\
\hline 18 & 50 & 132 & 45 & 0.90 & 0.34 \\
\hline 19 & 114 & 62 & 43 & 0.38 & 0.69 \\
\hline 20 & 3 & 101 & 1 & 0.33 & 0.01 \\
\hline 21 & 53 & 587 & 53 & 1.00 & 0.09 \\
\hline 22 & 14 & 477 & 7 & 0.50 & 0.01 \\
\hline 23 & 69 & 38 & 29 & 0.42 & 0.76 \\
\hline 24 & 27 & 28 & 26 & 0.96 & 0.93 \\
\hline 25 & 74 & 170 & 39 & 0.53 & 0.23 \\
\hline 26 & 64 & 58 & 35 & 0.55 & 0.60 \\
\hline 27 & 65 & 44 & 21 & 0.32 & 0.48 \\
\hline 28 & 19 & 276 & 15 & 0.79 & 0.05 \\
\hline 29 & 49 & 103 & 49 & 1.00 & 0.48 \\
\hline 30 & 27 & 23 & 23 & 0.85 & 1.00 \\
\hline Average & 39.13 & 164.30 & 27.93 & 0.73 & 0.33 \\
\hline
\end{tabular}

Figure 7 shows the graph before it is interpolated. Figure 8 then illustrated the graph between interpolated recall and precision for each query [24]. Recall and precision are based on Table 2 above. On average, precision drops as recall increases. The average of relevant judgement frequency, query result frequency, total of both relevant judgement and query result hadith, recall and precision of 30 queries are $39.13,164.30,27.93,0.73$ and 0.33 respectively. Considered high recall and high precision value is the most relevant answer for the search query. That shown the Mobile Application of Malay Translated Search Engine may provide the best result of user needs. For future research, more Hadith documents should be added to Malay Translated Hadith corpus from other prominent and reliable Hadith Books, such as Sahih Muslim, Sunan Al-Tarmizi, Sunan Al-Nasai', Sunan Ibnu Majah and Sunan Abi Daud [30]. Covering this large collection, will surely be the focal point of references. Another possible area of research is to cover crosslingual IR. This application will be able to support other language when user want to change the application language on setting menu. User will able to read the hadith and search in their own preference language. This will increase the target user range. 


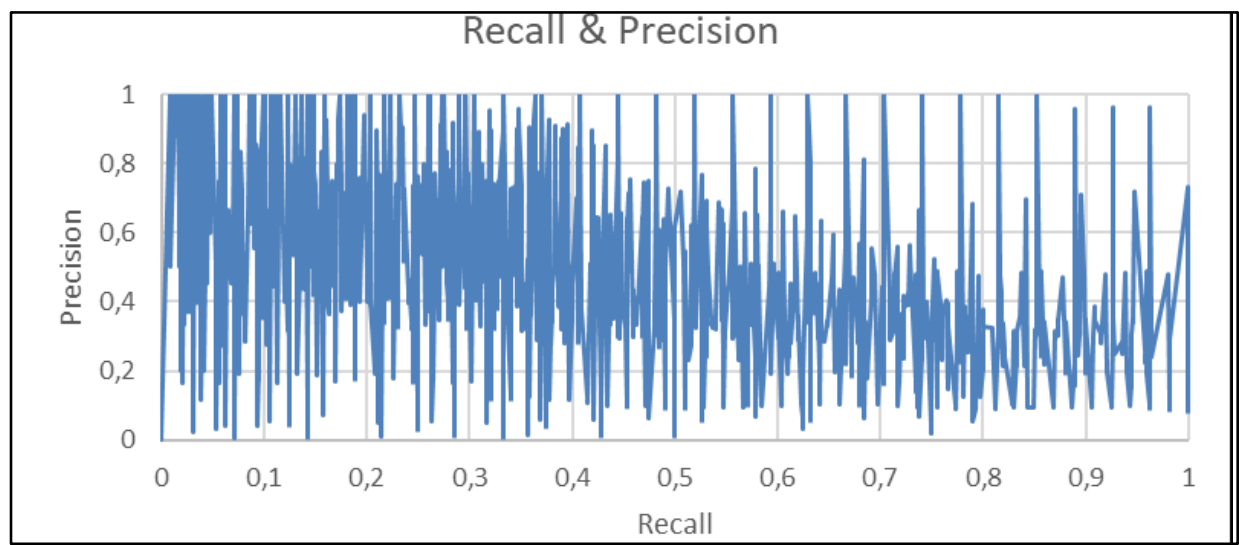

Figure 7. Recall and precision graph

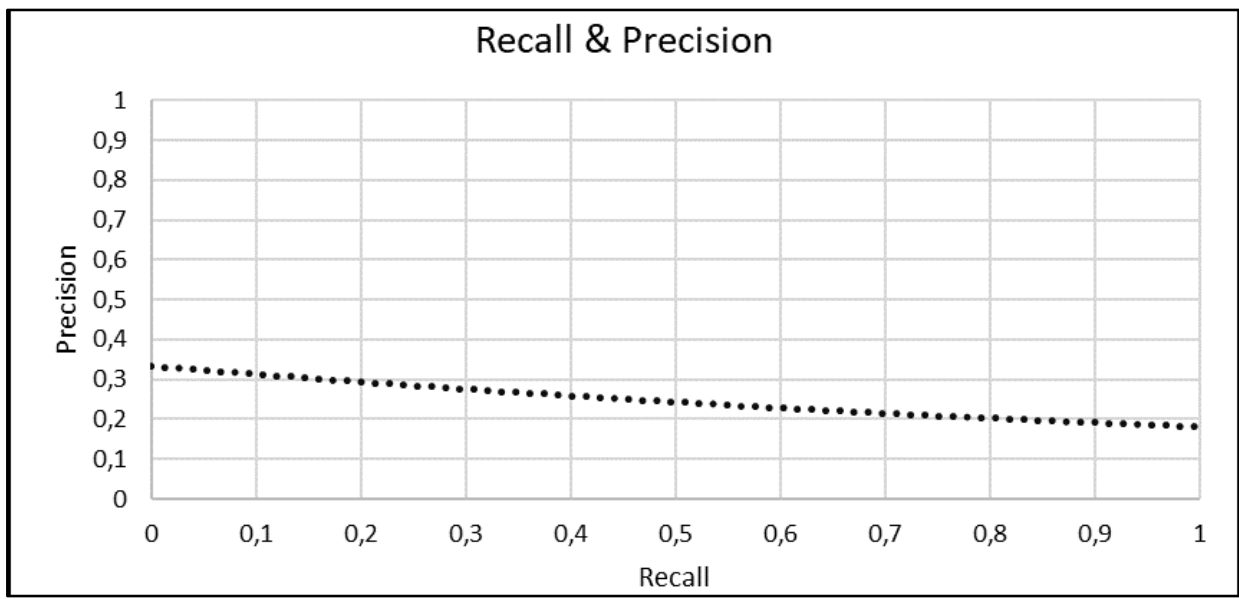

Figure 8. Interpolated recall and precision graph

\section{CONCLUSION}

In conclusion, the development of mobile application for Malay Translated Hadith Search Engine is highly needed to meet the proliferation of mobile users in the world generally and among Malay Speaking users in South East Asia specifically. Mobile platform offered easier way for users to search relevant information without the need for the internet.

\section{ACKNOWLEDGEMENTS}

This research is based upon work supported by Universiti Teknologi MARA BESTARI Grant 600IRMI/DANA 5/3/BESTARI(112/2018) and Faculty of Computer and Mathematical Sciences, Universiti Teknologi MARA, Shah Alam, Selangor, Malaysia.

\section{REFERENCES}

[1] Vaidya, A., Pathak, V., Vaidya, A., "Mobile phone usage among youth," International Journal of Applied Research and Studies (iJARS), vol. 5, no. 3, pp. 1-16, 2016.

[2] Hossain, M. M., "Impact of mobile phone usage on academic performance," World Scientific News An International Scientific Journal, vol.118, pp. 164-180, 2019.

[3] Peltonen, E., et. al., "The hidden image of mobile apps: geographic, demographic, and cultural factors in mobile usage," In Proc. of the 20th International Conference on Human-Computer Interaction with Mobile Devices and Services (MobileHCI '18). Association for Computing Machinery, pp.1-12, 2018.

[4] Singh, A.K., et. al., "Usage analysis of mobile devices," ScienceDirect Procedia Computer Science, vol. 122, pp 657-662, 2017. 
[5] Amirian P., Basiri, A., and Morley J., "Predictive analytics for enhancing travel time estimation in navigation apps of Apple, Google, and Microsoft," In Proceedings of the 9th ACM SIGSPATIAL International Workshop on Computational Transportation Science (IWCTS '16), pp. 31-36. 2016.

[6] Fernandez, K, "The history of Bahasa Melayu/Malaysia: The language of the Malay(sian) people," Expatgo Magazine, 2016, [Online]. Available: https://www.expatgo.com/my/2016/06/01/-history-bahasa-melayu-malaysia.

[7] Muhamad, M., Kamis, M. and Mat Junoh, A, "Bahasa Melayu versus English: a love-hate relationship?" SCUTREA, 33rd Annual Conference, University of Wales, Bangor, pp. 1-3, 2003.

[8] Khairul, A., Hussain, O., Zahrul, A., Lutfan, J., Fauziah, A., Shamsaadal, S., Khairol Anuar, K., "Memperkukuh Peranan Bahasa Melayu Dalam Dunia Teknologi," in Hussain Othman \& Rosman Md. Yusoff (ed.), Pendayaupayaan Bahasa, Agama dan Transformasi Masyarakat, pp. 1-18, UTHM, 2017.

[9] Alwazna, R.Y., "Islamic law: Its sources, interpretation and the translation of it into laws written in english," International Journal of Semiot Law, vol. 29, no. 2, pp. 251-260, 2016.

[10] Mokhtar, W. W. K. A., Khairuldin., W. M. K. F. W., Ima, A. M. M. M. M., "The authoritativeness of sunnah in the development of Islamic worldview research," International Journal of Education and Research, vol. 1, no.11, pp. 1-10, 2013.

[11] Zainudin, M. K. A. B., and Rias, R. M, "M-Hadith: Retrieving Malay Hadith text in a mobile application," in 2012 International Symposium on Computer Applications and Industrial Electronics (ISCAIE), (Iscaie), vol. 60-63. 2012

[12] Foundation, G. A, "Hadith Collection (All in one)," Milton Keynes, United Kingdom, 2016.

[13] Ummah, Q. P. B. Pro I. M., "Hadith Collection - Sahih Bukhari, Muslim \& More," Quarter Pi: Best pro-Islamic apps for Muslim Ummah, Gujrat, Pakistan, 2018.

[14] Labs, A.-R, "Hadith Sahih Al Bukhari Malay," Gulberg, Lahore, 2015.

[15] Bakar, Z. A., and Rahman, N. A, "Evaluating the effectiveness of thesaurus and stemming methods in retrieving malay translated Al-Quran documents," in T. M. T. Sembok, H. B. Zaman, H. Chen, S. R. Urs, \& S.-H. Myaeng (Eds.), Digital Libraries: Technology and Management of Indigenous Knowledge for Global Access, Berlin, Heidelberg: Springer Berlin Heidelberg, 653-662, 2003.

[16] S. B. Rodzman, M. F. Izuan Abdul Ronie, N. K. Ismail, N. A. Rahman, F. Ahmad and Z. M. Nor, "Analyzing malay stemmer performance towards fuzzy logic ranking function on malay text corpus," 2018 Fourth International Conference on Information Retrieval and Knowledge Management (CAMP'18), pp. 1-6, 2018.

[17] N. S. Syazhween Binti Zulkefli, N. B. Abdul Rahman, M. B. Puteh and Z. B. Abu Bakar, "Effectiveness of latent dirichlet allocation model for semantic information retrieval on malay document," 2018 Fourth International Conference on Information Retrieval and Knowledge Management (CAMP'18), Kota Kinabalu, pp. 1-5, 2018.

[18] N. N. Amirah, T. M. Rahim, Z. Mabni, H. M. Hanum and N. A. Rahman, "A Malay Hadith Translated Document Retrieval Using Parallel Latent Semantic Indexing (LSI)," 2016 Third International Conference on Information Retrieval and Knowledge Management (CAMP'16), Bandar Hilir, pp. 118-123, 2016.

[19] Rahman N. A., Soom A. B. M., Ismail N. K. "Enhancing latent semantic analysis by embedding tagging algorithm in retrieving malay text documents," In: Król D., Nguyen N., Shirai K. (eds) Advanced Topics in Intelligent Information and Database Systems. ACIIDS 2017. Studies in Computational Intelligence, vol. 710. Springer, 2017.

[20] N. Alias, N. A. Rahman, N. K. Ismail, Z. M. Nor and M. N. Alias, "Graph-based text representation for Malay translated hadith text," 2016 Third International Conference on Information Retrieval and Knowledge Management (CAMP'16), Bandar Hilir, pp. 60-66, 2016.

[21] Mohd Syukri, M. N., Norazmi, A., Shahril Nizam, Z., Amran, A. H., Ahmad Sanusi, A., Syed Najihuddin, S. H., "Pendigitalan Hadis Dalam Kerangka Revolusi Industri 4.0," The 5th World Conference on Islamic Thought \& Civilization: Securing The Future (WCIT2018), pp.67-81. 2018..

[22] Zulkefli, N. S. S., Abdul Rahman, N., and Puteh, M, "A survey: Framework of an information retrieval for Malay translated Hadith document," in MATEC Web of Conferences, vol. 135, p. 00073, 2017.

[23] Kato Mivule "Web Search query privacy, an end-user perspective," Journal of Information Security, vol. 8, no.1, pp. 56. Jan 17, 2017.

[24] Baeza-Yates, R. and Ribeiro-Neto, B., "Modern Information Retrieval”, ACM Press, New York, vol. 463, 1999.

[25] Rahman, N. A., Mabni, Z., Omar, N., Hanum, H. F. M., and Rahim, N. N. A. T. M, "A parallel latent semantic indexing (LSI) algorithm for Malay Hadith translated document retrieval," M. W. Berry, A. Mohamed, \& B. W. Yap (Eds.), Soft Computing in Data Science, Singapore: Springer, 154-163, 2015.

[26] Pratama, E. P., et. al., "Weighted inverse document frequency and vector space model for Hadith search engine", Indonesian Journal of Electrical Engineering and Computer Science, vol. 18, no. 2, pp. 1004-1014, 2020.

[27] Shahzad, A., Jacob, W.D., Nawi, M. N., Mahdin, H., Saputri, M. E., "The new trend for search engine optimization, tools and techniques," Indonesian Journal of Electrical Engineering and Computer Science (IJEECS), vol. 18, no. 3, pp. 1568-1583, 2020.

[28] Althaf Ali A, R. Mahammad Shafi, "Test-retrieval framework: performance profiling and testing web search engine on non factoid queries," Indonesian Journal of Electrical Engineering and Computer Science (IJEECS), vol. 14, no. 3, pp. 1373-1381, 2019.

[29] Abu Bakar, Z., Abdul Rahman, N., "Evaluating the effectiveness of thesaurus and stemming methods in retrieving malay translated al-quran documents," International Conference on Asian Digital Libraries, Springer Verlag, vol. 2911, pp 653-662, 2003.

[30] N. Abd Rahman, Z. Abu Bakar and N. S. S. Zulkefli, "Malay document clustering using complete linkage clustering technique with cosine coefficient," 2015 IEEE Conference on Open Systems (ICOS2015), Bandar Melaka, pp. 103-107, 2015. 


\section{BIOGRAPHIES OF AUTHORS}
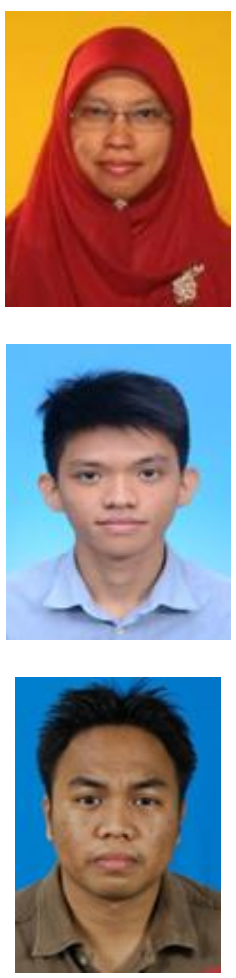

Nurazzah Abdul Rahman (PhD) is an Associate Professor at Computer Science Department, Faculty of Computer and Mathematical Sciences in UiTM, Shah Alam. Her main research area is Information Retrieval (IR), focuses in Malay Text IR specifically in Malay Translated Hadith Text corpus and Information Extraction. She is also an active member of IEEE CS Malaysia Chapter and the Society of Information Retrieval and Knowledge Management (PECAMP). Currently, she is the Head of Research Interest Group MuDIR - Multidisciplinary Information Retrieval, UiTM.

Faiz Ikhwan Mohd Rafhan Syamil (BSc), a Bachelor Degree student at Faculty of Computer and Mathematical Sciences in UiTM, Shah Alam. He is very interested in mobile application development. He is currently working as Android Developer in a software development company at Petaling Jaya. He developed several mobile applications either native Android and iOS or using hybrid framework before this. He also joined six competitive programming competition during his study.

Shaiful Bakhtiar bin Rodzman (MSc), a Ph.D. student and Research Assistant at Computer Science Departments of Faculty of Computer and Mathematical Sciences in UiTM, Shah Alam. His research interests focus on Ranking Function of the Malay Information Retrieval, Malay Document Retrieval Framework and the Fuzzy Logic. He has joined various product innovation competitions in the field of Financial and Information Retrieval. He had worked for six years in Financial Institution, Statistic and the Software company. 